\section{FRESHWATER TURTLES OF RIVER YAMUNA FROM BATESHWAR (FIROZABAD) TO DIBHOLI (ETAWAH), UTTAR PRADESH.}

\section{S. Narain, Anjana Tiwari and S. B. Mishra}

P.G. Dept. of Zoology, Janta College, Bakewar (Etawah), Uttar Pradesh, India

Freshwater turtles play an important part in cleaning the waters of polluted rivers by consuming dead animals. Turtles are exploited for food by local people.

Studies on the freshwater turtles in India are very few while India is very rich in chelonian fauna. A few notable works are Singh (1985), Rao (1986), Rao \& Singh (1987) and Mishra et al. (1996).

A survey was done in the river Yamuna from Bateshwar to Dibholi. Field surveys were conducted in the $25 \mathrm{~km}$. river stretch in the following localities; Bateshwar, Kachaura Ghat, Etawah and Dibholi as shown in the area map. Weekly survey of each station was done from September 1997 to October 1998.

The methods used for turtle identification were those of Das (1995) and Das \& Moll (1991).

Two types of turtles were observed during exploration:

(1) Softshell Turtles: (a) Aspideretes gangeticus (Cuvier, 1825) Indian Soft Shelled Turtle; (b) Lissemys punctata (Lacepede, 1788) Indian Flap Shell Turtle; (c) Chitra indica (Gray, 1831) Narrow-headed Soft Shelled Turtle

(2) Hardshell turtles: (a) Kachuga tentoria (Gray, 1834) Indian Tent Turtle; (b) Kachuga dhongoka (Gray, 1834) Three-striped Roofed Turtle; (c) Kachuga kachuga (Gray, 1831) Red-crowned Roofed Turtle

During survey on the freshwater turtles from Bateshwar to Dibholi, 6 species of turtles were identified. In Bateshwar, $C$. indica, $A$. gangeticus, $L$. punctata and $K$. tentoria were found. $K$. kachuga was found only in Etawah. $C$. indica was found only in Bateshwar. K. tentoria is the most abundant and encountered in all stations. $K$. kachuga and $C$. indica are endangered species. The turtles were mainly found where the depth of water is much and flow of water vary. It provides a good habitat to the turtle. Ninety nests of different species were recorded and predation was markedly high.

Received 15 February 1999;

Accepted 15 April 1999
Rapacious turtling has continued over the years and very few attempts have been made to study the turtle from the conservation angle (Khan, 1982; Moll \& Vijaya, 1986; Moll, 1986,87,91; Moll et al., 1987; Das, 1990; Ahsan et. al., 1989; Frazier, 1992; Vyas \& Patel, 1990; Bhupathy \& Vijayan, 1991). The area is very suitable for turtle breeding but it is dacoit infested and unsafe. Therefore, there is need to start effective steps to save them. Hunting, fishing and egg collection should be prohibited and conservation activites should be taken at the earliest.

\section{Acknowledgement}

The authors express their gratitute to the Secretary and Principal Janta College Bakewar (Etawah) for providing necessary Laboratory facilities in the Deptt. We are also grateful to Shri G. N. Yadav, Wild Life Warden, National Chambal Sanctuary, Etawah and Mr. D. Basu who have cooperated with us in different ways.

\section{References}

Ashan, Md. F. and Md. A Saeed (1989). The Bostami turtle Trionyx nigricans Anderson; Poputation status, distribution, historical background and length weight relationship. J. Bombay nat. Hist. Soc. 86(1): 1-6.

Bhupathy, S. and V.S. Vijayan (1991). The freshwater turtle fauna of Eastern Rajasthan. J. Bombay nat. Hist. Soc. 88(1): 118-122.

Das, I. (1995). Turtles and Tortoises of India. Oxford University Press, Walton Street Oxford.

Das, I. (1990). Distributional records for chelonians from Northeastern India. J. Bombay nat. Hist. Soc. 87(1): 91-97.

Das, I. and E.O. Moll (1991). Colour guide to the turtles and tortoises of the Indian sub continent.

Frazier, J. (1992). Management of tropical chelonians: Dream or nightmare. In: Tropical Ecosystem: Ecology and Management. Eds. K.P. Singh and J.S.Singh, Wiley Eastern Limited: 125-135.

Khan, M.A.R. (1982). Chelonians of Bangladesh and their conservation. J. Bombay nat. Hist. Soc. 79(1): 110-116.

Mishra S.B., S. Narain and R. Chauhan (1996). Study of some fresh water turtles of Panchnada. J. Nat. Con. 8(1): 121-133.

Moll, E.O. (1986). Survey of the Freshwater Turtles of India Part I: The Genus Kachuga. J. Bombay nat. Hist. Soc. 83(2): 538-552.

Moll, E.O. (1987). Survey of the Freshwater Turtles of India Part II :The Genus Kachuga. J. Bombay nat. Hist. Soc. 84(1): 7-25.

Moll, E.O. (1991). India's Freshwater Turtle resource with recommendations for management. In: Conservation in developing countries: Problems and prospects. J.C. Daniel and J.S. Serrao (Eds.) Bombay Natural History Society and Oxford University Press, Bombay. pp 501-515.

Moll, E.O., B. Groombridge and J.Vijaya (1987). Rediscription of the Cane Turtle with notes on its natural history and classification. $J$. Bombay nat. Hist. Soc. 83(supplement): 112-126.

Moll, E.O. and J.Vijaya (1986). Distributional records for some Indian turtles. J. Bombay nat. Hist. Soc. 83(1): 57-62.

Rao R.J. (1986). Freshwater turtles conservation in National Chambal Sanctuary. Tiger Paper. 13: 28-29.

Rao R.J. and L.A.K. Singh (1987). Note on ecological relationship in basking and nesting site utilisation among Kachuga sps. (Reptilia: Chelonia) and Gavialis gangeticus (Reptilia: Crocodilia) in National Chambal Sanctuary. J. Bombay nat. Hist. Soc. 84: 599-604.

Singh L.A.K. (1985). Notes on Tracking and Terrestrial activities of the Freshwater turtles K.tentoria in river Mahanadi, Orissa. J. Bombay nat. Hist. Soc. 82(2): 414-417. 
Vyas, R. and B.H. Patel (1990). A survey of freshwater turtles of Gujarat. J. Bombay nat. Hist. Soc. 87(1): 152-155.

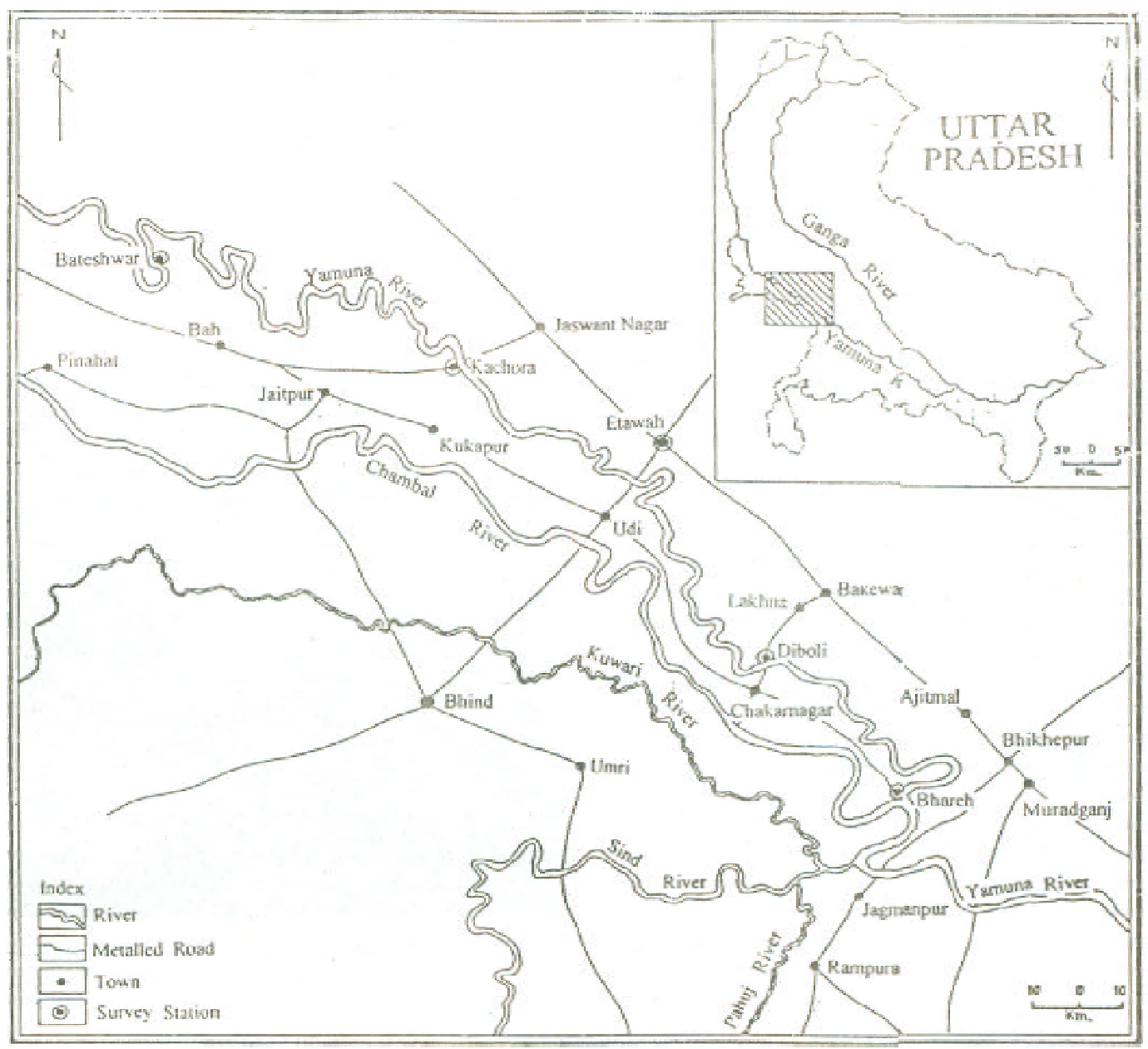

Figure 1. Pachnada Region. Yamuna River from Bateshwar to Bhareh

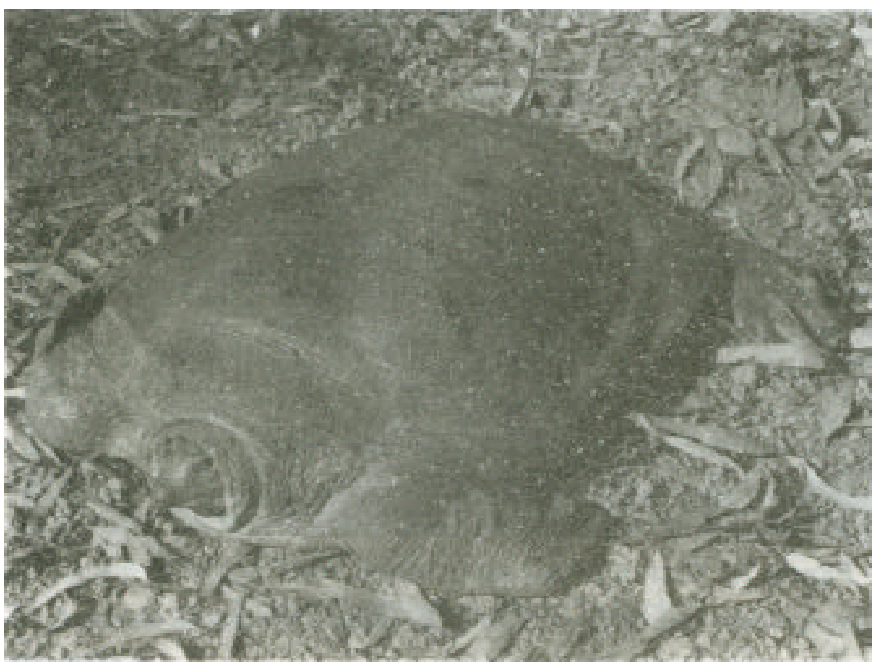

Figure 2. Aspideretes gangeticus, dorsal view (carapace).

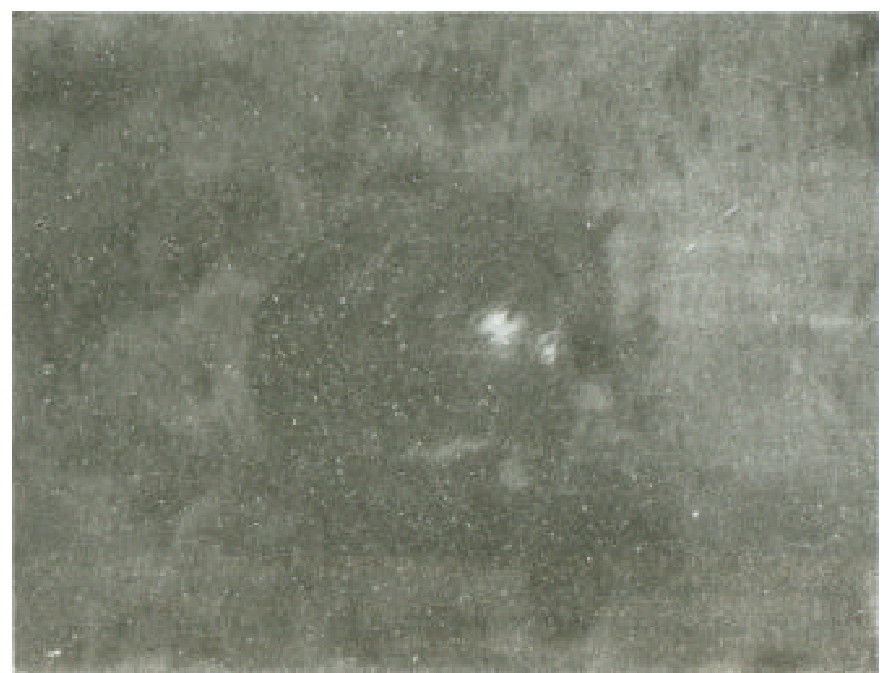

Figure 3. Lissemys punctata, dorsal view (carapace). 
Table 1. Morphometry measurements of species are given in the table below:

\begin{tabular}{llllll}
\hline Species & $\begin{array}{l}\text { No. } \\
\text { observed }\end{array}$ & $\begin{array}{l}\text { Carapace } \\
\text { length (in) }\end{array}$ & $\begin{array}{l}\text { Plastron } \\
\text { length (in) }\end{array}$ & $\begin{array}{l}\text { Plastron } \\
\text { width (in) }\end{array}$ & $\begin{array}{l}\text { Weight } \\
\text { (Kg.) }\end{array}$ \\
\hline 1. Aspideretes gangeticus & $\mathrm{n}=9$ & 43.5 & 36.7 & 32.55 & 8.020 \\
2. Lissemys punctata & $\mathrm{n}=4$ & 17.5 & 14.4 & 15.95 & 0.660 \\
3. Chitra indica & $\mathrm{n}=2$ & 34.7 & 29 & 31 & 4.000 \\
4. Kachuga tentoria & $\mathrm{n}=11$ & 21.75 & 18 & 16.9 & 1.100 \\
5. Kachuga dhongoka & $\mathrm{n}=10$ & 21.3 & 18.13 & 15.76 & 1.43 \\
6. Kachuga kachuga & $\mathrm{n}=2$ & 46 & 40.1 & 21.2 & 13.750 \\
\hline
\end{tabular}

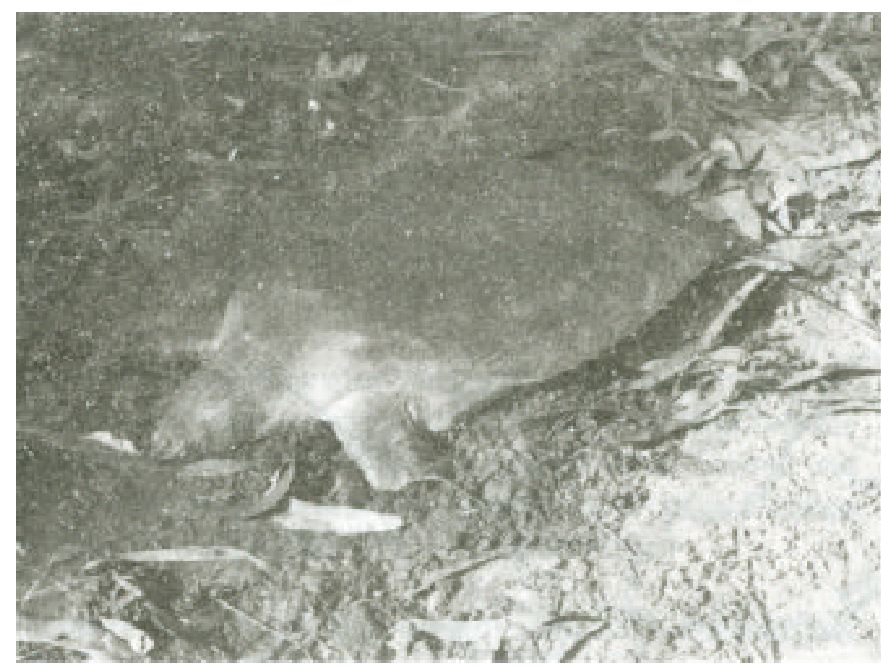

Figure 4. Chitra indica, dorsal view, showing a pattern of wavy reticulations. The neck has longitudinal streaks

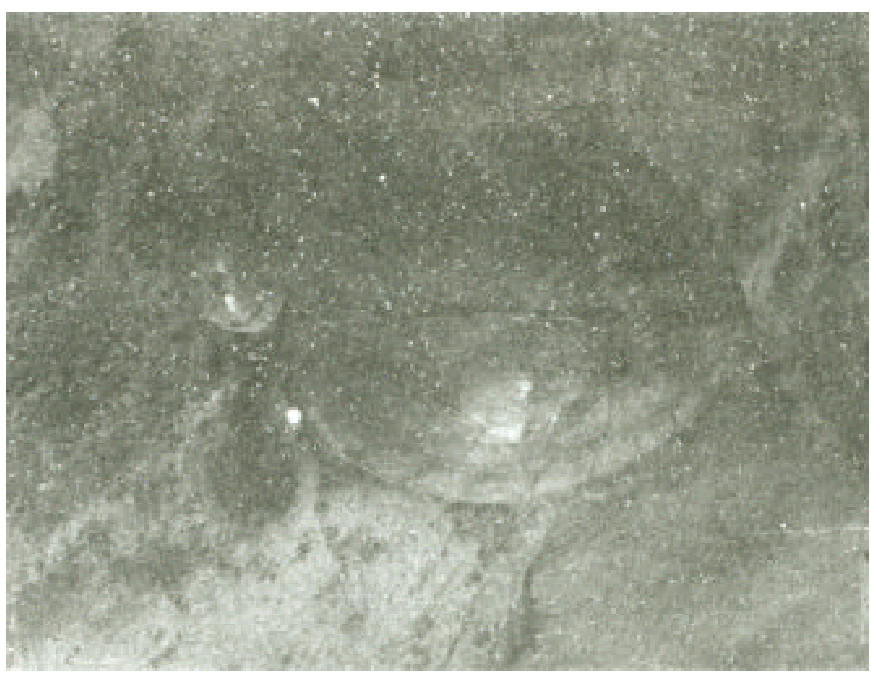

Figure 6. Kachuga dhongoka, dorsal view, showing black stripes above median keel extending from nuchal up to posterior margin of the carapace

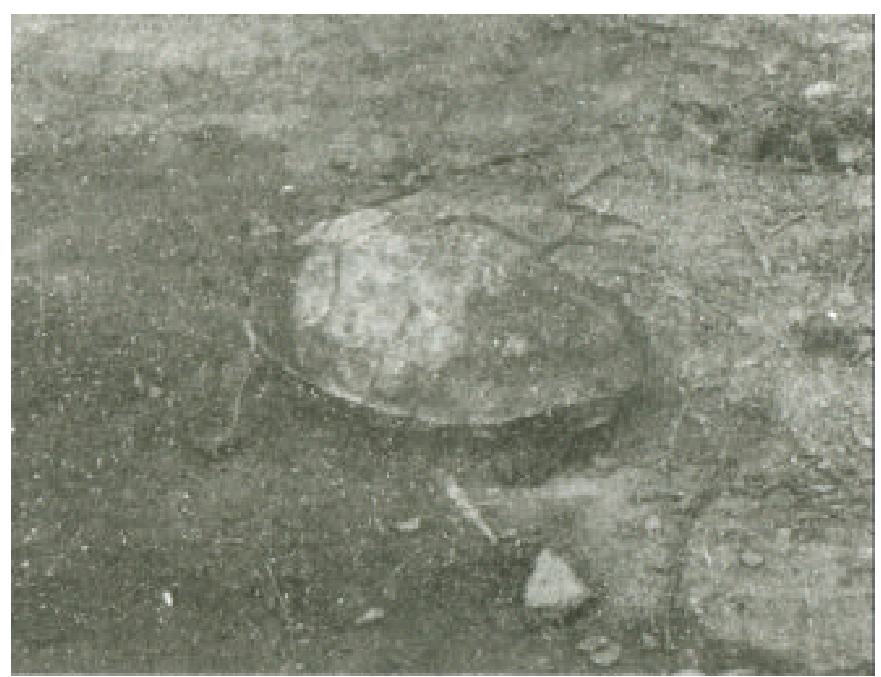

Figure 5. Kachuga tentoria, dorsal view, showing a pink ring along the peripheral marginal junction

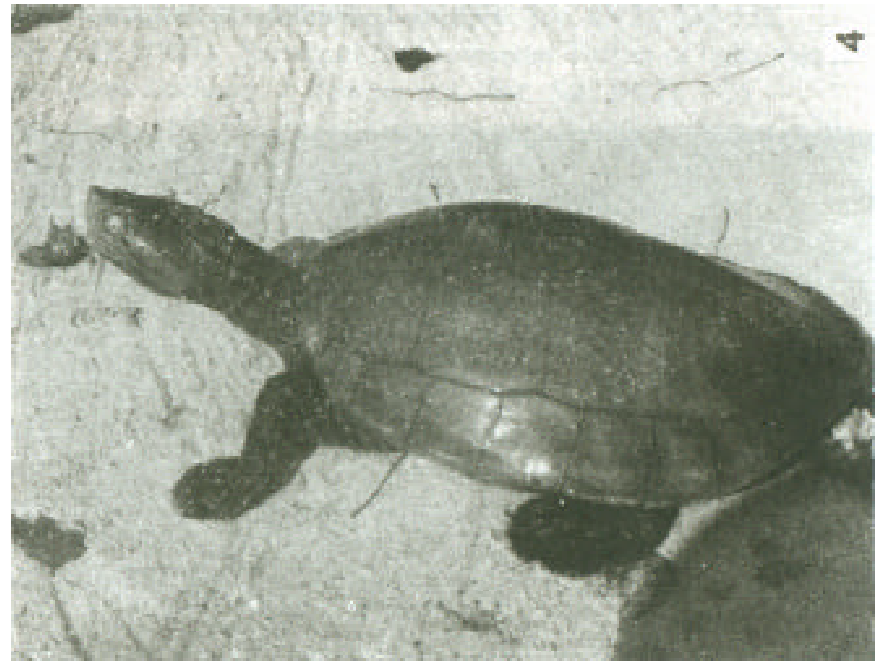

Figure 7. Kachuga kachuga, dorsal view, showing a red coloured patch between the eyes. 